\title{
Correction to: Gender norms about romantic relationships and sexual experiences among very young male adolescents in Korogocho slum in Kenya
}

\author{
Beatrice W. Maina ${ }^{1,2}$ (D) $\cdot$ Benedict O. Orindi $^{2}$ (D) Yandisa Sikweyiya $^{1,3}$ (D) Caroline W. Kabiru $^{1,4}$ (D) \\ Published online: 3 November 2020 \\ (c) The Author(s) 2020
}

\section{Correction to: International Journal of Public \\ Health (2020) 65:497-506 \\ https://doi.org/10.1007/s00038-020-01364-9}

The authors would like to correct an error in the publication of the original article. The error is described below and correct details provided. What is presented in the lines 23 , 29,38 , and in table 4 is the corrected version.

\section{Error}

On page 503, Table 4, the labels on pubertal maturation variables were swapped. This resulted in an erroneous interpretation of the finding on page 502 and discussion of the finding on 503 and 504 (Table 4).

The original article can be found online at https:// doi.org/10.1007/s00038-020-01364-9.

Beatrice W. Maina

bmaina@aphrc.org

Benedict O. Orindi

benedict.orindi@gmail.com

Yandisa Sikweyiya

Yandisa.Sikweyiya@mrc.ac.za

Caroline W. Kabiru

carolinekabiru@gmail.com

1 School of Public Health, University of the Witwatersrand, Johannesburg, South Africa

2 African Population and Health Research Center, APHRC Campus, Manga Close, Off Kirawa Road, P.O. Box 10787-00100, Nairobi, Kenya

3 Gender and Health Research Unit, South African Medical Research Council, Pretoria, South Africa

4 Population Council, Nairobi, Kenya

\section{Correction}

\section{Results: Associations between sexual experiences and gender norms}

Page 502: Second paragraph, first sentence

Boys who had experienced any pubertal changes, those below the recommended grade for age and those who had missed school at any time during the 6 months preceding the survey were more likely to report sexual activity.

\section{Discussion}

Page 503, last paragraph extending to page 504

First sentence: Our study also found that boys who reported pubertal changes were more likely to have had a sexual experience compared to those who reported no pubertal changes suggesting that pubertal changes are associated with initiation of sexual activity. Sexual development is a major component of pubertal maturation (Fortenberry 2013; Kar et al. 2015).

Page 504, first paragraph (same paragraph as above), last sentence

Our findings underscore the need for programs to target young boys as they get into puberty especially those that live in contexts that expose them to sexual risks at an early age. 
Table 4 Association between gender norms endorsement domains and sexual behavior of very young male adolescents in Korogocho slums, Kenya 2018

\begin{tabular}{|c|c|c|c|}
\hline \multirow[t]{2}{*}{ Parameter } & \multicolumn{3}{|c|}{ Sexual experience } \\
\hline & Estimate & Standard error & $P$ value \\
\hline \multicolumn{4}{|l|}{ Gender norms factors } \\
\hline Sexual double standard & 0.045 & 0.065 & 0.490 \\
\hline Normative romantic relationships & -0.384 & 0.063 & $<0.001$ \\
\hline \multicolumn{4}{|l|}{ Age } \\
\hline $10-12$ & Ref & & \\
\hline $13-14$ & 0.128 & 0.154 & 0.406 \\
\hline \multicolumn{4}{|l|}{ Place of birth } \\
\hline Nairobi & Ref & & \\
\hline Outside Nairobi & -0.288 & 0.145 & 0.047 \\
\hline \multicolumn{4}{|l|}{ Pubertal maturation } \\
\hline Not started puberty & Ref & & \\
\hline Started puberty & 0.330 & 0.146 & 0.024 \\
\hline \multicolumn{4}{|l|}{ Sleeping arrangements } \\
\hline 1-2 people & Ref & & \\
\hline 3-4 people & -0.644 & 0.176 & $<0.001$ \\
\hline 5 or more people & -0.299 & 0.177 & 0.091 \\
\hline \multicolumn{4}{|l|}{ Age of household head } \\
\hline Below 50 years & Ref & & \\
\hline 50 years and above & -0.295 & 0.143 & 0.039 \\
\hline \multicolumn{4}{|l|}{ Grade for age } \\
\hline Recommended grade or above & Ref & & \\
\hline Below recommended grade & 0.296 & 0.135 & 0.028 \\
\hline \multicolumn{4}{|l|}{ School absenteeism (past month) } \\
\hline Never missed school & Ref & & \\
\hline Ever missed school & 0.348 & 0.139 & 0.012 \\
\hline
\end{tabular}

Open Access This article is licensed under a Creative Commons Attribution 4.0 International License, which permits use, sharing, adaptation, distribution and reproduction in any medium or format, as long as you give appropriate credit to the original author(s) and the source, provide a link to the Creative Commons licence, and indicate if changes were made. The images or other third party material in this article are included in the article's Creative Commons licence, unless indicated otherwise in a credit line to the material. If material is not included in the article's Creative Commons licence and your intended use is not permitted by statutory regulation or exceeds the permitted use, you will need to obtain permission directly from the copyright holder. To view a copy of this licence, visit http://creativecommons. org/licenses/by/4.0/.

\section{References}

Fortenberry JD (2013) Puberty and adolescent sexuality. Horm Behav 64(2):280-287. https://doi.org/10.4103/0974-1208.158594

Kar SK, Choudhury A, Singh AP (2015) Understanding normal development of adolescent sexuality: A bumpy ride. J Hum Reprod Sci 8(2):70. https://doi.org/10.4103/0974-1208.158594

Publisher's Note Springer Nature remains neutral with regard to jurisdictional claims in published maps and institutional affiliations. 